
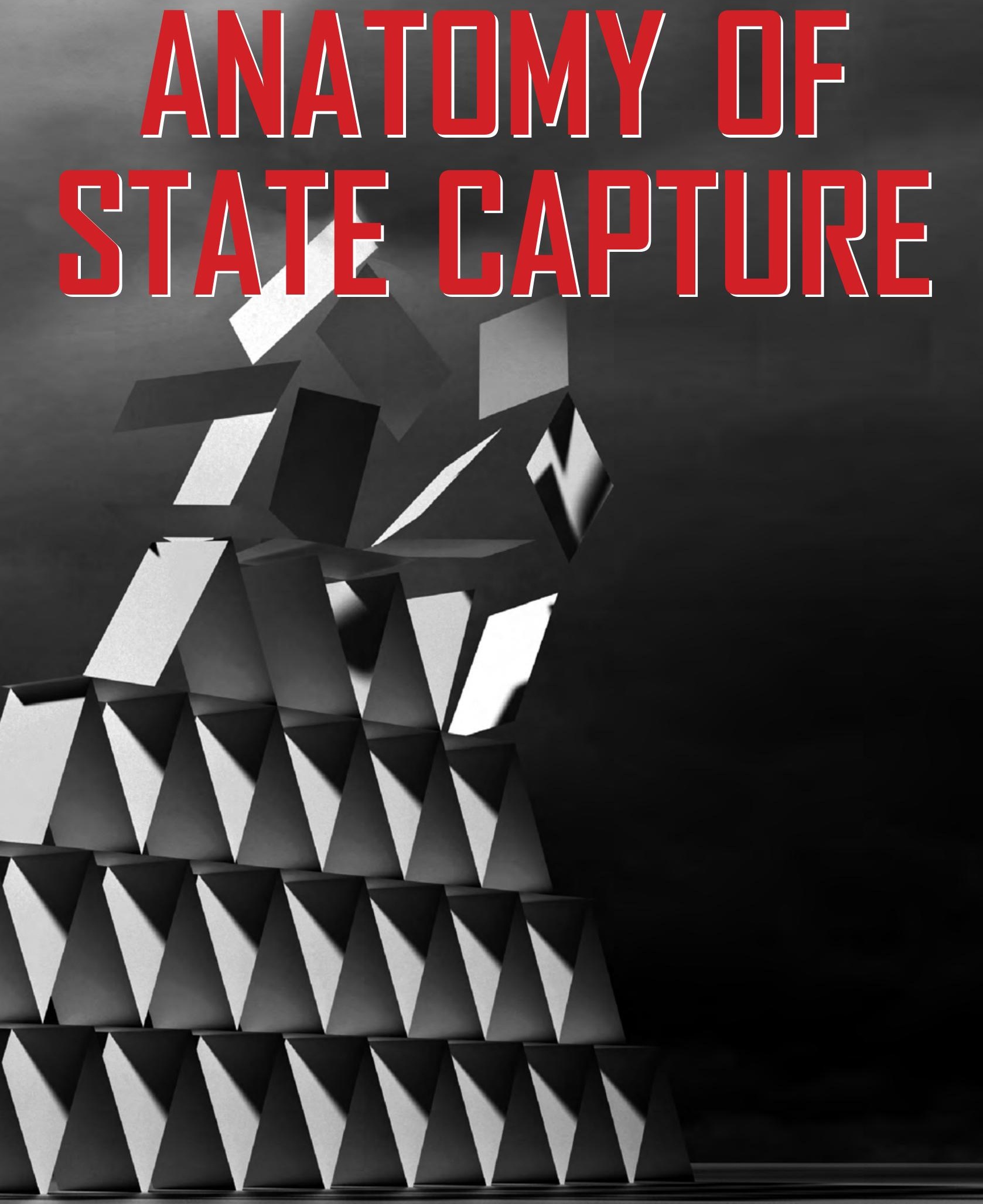

Nina Callaghan, Rabyn Foley and Mark Swilling (EDITuRS) 


\section{A LONG SHADOW: STATE CAPTURE UNDER APARTHEID AND AFTERWARDS}

Hennie van Vuuren

\subsection{INTRODUCTION}

There is an obsession with the politics of the moment in South Africa that risks trapping our imagination. Political scandals and human rights abuses are magnified by an intense social media focus of millions of eyes on screens on any given day, only to be dropped by the next morning for another, equally compelling, focus of outrage. Missing in our collective understanding seems to be a consensus that these patterns of abuse and behaviour are replicated over years. When the past is brought into focus, it is too often only as a proxy to again reinforce existing positions.

The same could be said of how we view corruption and state capture - the economic crimes that have settled in our politics to such an extent it dominates part of the public discourse. The cast of the corrupt who benefit from these crimes is complex and the voices of the people who carry this burden are treated as marginal. The intersection of groups of political elites in each scandal ensures that a constituency of supporters can be rallied to supply disinformation or claim political victimisation.

This is a situation that favours the powerful. Some of the more recent analysis of state capture that characterised the administration of Jacob Zuma is an example of this. This suggests that the set of conditions which allowed such rampant state looting to take place are not in fact a culmination of practice years which preceded Zuma's administration. This view fails to identify the role of the economic crimes of apartheid and the early democratic period as contributors to state capture. By ignoring this evidence, we fail to recognise that there was no neat clean break with the past.

Instead, networks of corporate influence and the middlemen who often broker shady deals have morphed and persisted since apartheid. We see these continuities in the multi-billion-rand arms acquisition of the Mbeki administration, which was bedevilled by large scale corruption and represented continuity of apartheid practice. It also signalled the beginning of a sustained fightback against the promised new norms of a Constitutional democracy. The politicians, middlemen and corporations 
who befitted from the arms deal and subsequent malfeasance worked relentlessly to dismember independent democratic institutions - setting the scene for state capture.

While Jacob Zuma's political fire may have been largely vanquished, the networks have not simply disappeared overnight. Many of these people and institutions have worked hard to launder their reputations, just as they did at the end of apartheid and threaten to continue the process of extraction and looting in a different guise. It remains imperative that any analysis of state capture and large-scale corruption is anchored by an understanding of the past. Our failure to deal decisively with networks of the past should not present a constraint on present action, rather it helps us understand the linear nature of processes of criminal extraction. If we fail to do so, we risk being trapped by cycles of repetition and the deepening inequality and poverty which these entrench.

Much of the analysis in this chapter is attributed to work produced as part of Apartheid Guns and Money: A tale of Profit (Van Vuuren, 2017), one of the few texts to attempt to grapple with the full extent of a 'hidden' aspect of South Africa's recent past. It draws from five years of research and sifting through millions of pages of archival documents and dozens of interviews which inform this analysis.

\subsection{BACK TO THE ORIGINAL SIN}

To understand state capture today, it is crucial that we examine the period in South Africa's history from the mid 1970s to the mid 1990s. During this 20-year period, a mix of factors gave rise to a perfect storm that left an indelible impact on our history and society. It was a time of unparalleled abuse of power. When the struggle for South Africa's freedom was at its fiercest, economic crime not only festered, but became state policy. Corruption, money laundering, sanctions busting and organised crime, the elements of such economic crime, had become a necessity for the survival of the state.

An outlier in our understanding of apartheid practice has been the issue of corruption and economic crime in the post-apartheid period. It did not start to manifest the day that the Mandela administration was inaugurated. Our conception of South Africa as a 'new' nation was a helpful tool to build national unity at a key moment, but it has also meant that we have denied uncomfortable truths. When Nelson Mandela was elected President, his government had to craft a new administration from disparate authorities in former white-administered provinces and ethnic black homelands alike. He had to deal with the internal contradictions of a liberation movement that was infiltrated by the apartheid regime and also counted crooks and opportunists amongst its ranks. Some individuals of questionable ethical character, such as uMkhonto we Sizwe (MK) leader Joe Modise, would become South Africa’s first Minister of Defence 
and a beneficiary of commercial contracts linked to the corruption riddled Arms Deal of the late 1990s (Holden \& Van Vuuren, 2011). Added to this mix was the existence of a powerful private sector dominated by white business interests that had a habit of betting on the short term.

The democratic elections in 1994 and the finalisation of the Constitution two years later signalled a commitment to integrity and to the creation of public institutions that sought to uphold these principles. With this, a message was sent that corruption at all levels would not be tolerated. But this important process had a caveat: corruption and economic crime in the past would be left to lie, like fat, rich sleeping dogs. To have looked backwards and prosecuted past crimes at that exact moment could have wrecked the peacemaking process.

Firstly, it would have led to the seat of power in various apartheid Bantustans, many of whom had become mired in corruption and the politics of patronage, which we have seen deep into the political DNA in a number of present day local and provincial government institutions (Lodge, 1998, 2014).

Secondly, and importantly for the focus of this chapter, thorough investigation would have touched powerful interest groups across the globe: bankers, arms dealers, political parties, foreign leaders, arms companies, oil traders, lobbyists, foreign intelligence agencies and the domestic military. They were all implicated in a largely criminal economy that was thought best left buried - even if we recognise, in hindsight, that this was folly.

The apartheid economy had, in the preceding 15 years, built a massive infrastructure to bust international sanctions. With the help of friends across the globe who sensed profit, a criminal economy was put in place to sustain white power. A highly secretive machinery was created to protect corrupt politicians, launder public and private funds, and break international sanctions. This effectively criminalised key institutions within the public and private sector, and it relied extensively on the support of rightwing business, political and intelligence networks across the globe.

This pervasive international system - a war machine - remains a largely hidden aspect of our past. So, too, does the identity of the multitude of individuals who created and ran it. Nevertheless, there is no doubt that the war machine was an essential element of the survival of PW Botha's government and the political fortunes of his Ministers, such as FW de Klerk. The machinery funded war and violence in South Africa and elsewhere. National Party (NP) politicians and their allies in business became enmeshed in a sinister world governed by the interests of right-wing forces, neo-conservatives and anti-democratic regimes. Even the South African parliament, 
which existed for minorities only, was largely blind to the extent of these endeavours. These were deep shadow state networks that operated outside the law in South Africa and other countries. Gallingly, many of the countries that aided and abetted apartheid had officially supported sanctions against South Africa's racist regime and, in certain instances, openly funded the liberation movements.

All this came at great cost. It required money and a reliance on intelligence structures, particularly within the military, to manage these power networks. To bust sanctions, to buy guns and oil and other goods, required ideological affinity, race-based sympathy and money in vast quantities.

\subsection{ELEMENTS OF THE CRIME}

Networks of sophisticated corruption in largely democratic environments, such as contemporary South Africa, are faced with the challenge of openness and the resistance presented by social justice movements and public interest minded media who assert their legal rights to accountability and the free flow of information. In comparison, authoritarian regimes, such as the apartheid state, work hard to remain unshackled of such burdens.

Five important elements helped maintain the apartheid networks of economic crime and protect their allies in the private sector and across the globe. It is important to recognise the effectiveness of these given that, despite their dogged efforts, the antiapartheid movement was only able to scratch the surface in exposing these crimes.

Firstly, heightened state secrecy was key to the plan, criminalising any reporting be it by journalists or nominally independent oversight mechanisms - that could undermine the anti-sanctions effort. The security state became a central tenet of PW Botha's administration. In the process, the public were fooled into complacency after the apartheid-era Information Scandal of the late 1970s, which led to the more sinister, secret, money-for-arms machine developed by Botha's securocrats. It was far larger than the Information Scandal by an order of magnitude. All government departments were drawn into the anti-sanctions effort in different ways. Within the defence force, the establishment of Armscor as the state-owned arms company was a crucial element. It established an international network to procure weapons and technology, which were reproduced or improved at home, tested in battle in countries such as Angola, and then subsequently marketed overseas to foreign clients as a source of foreign revenue.

Secondly, a secret economy was required that bound the interests of domestic corporations into the 'anti-sanctions' campaign. Reliant on procurement by the state for its growing war economy, corporations were accomplices to the project of the NP 
- funding the party, defending the status quo and busting sanctions as required. A key element of the secret economy was the covert channelling of oil to South Africa from across the globe by supplier countries, traders and shipping companies that reaped the profits from the premiums they were able to charge.

Thirdly, trusted banking allies were called on to keep the lines of credit flowing in the face of growing calls from the anti-apartheid movement that apartheid should no longer have access to easy money on international capital markets. This was successful, thanks in part to the European lenders. However, the banks also played a far more sinister role. They acted as money launderers for at least R50bn (more than half a trillion rand in current values) used to purchase weapons on the international market (Van Vuuren, 2017). The 1980s - which ushered in electronic banking systems connected via primitive internet-like networks that made the large-scale, rapid movement of cash across the globe easy and instantaneous - could not have come sooner. Armscor, with requisite approval from the Reserve Bank and the executive, began to move cash between front companies in Panama and Liberia, with the complicity of two notable European banks - Kredietbank in Belgium and its affiliate Kredietbank Luxembourg in particular (Van Vuuren, 2017).

Fourthly, allies were called on to secretly lend a hand. The most important group were the "Big Five" permanent members of the UN Security Council, the most powerful nations on earth at the time and the biggest arms manufacturers. France was an old ally that looked the other way despite a socialist President. The United Kingdom and the United States were far safer bets with the emergence of the conservative governments of Ronald Reagan and Margaret Thatcher. Their brand of neo-liberalism wanted apartheid 'reformed' without fundamentally challenging white rule. Within all these countries there is significant evidence of deep state networks at play - the confluence of interests between intelligence sectors, governments, corporations, arms producers and political parties. At the other end of the Cold War spectrum, we saw that the liberation movement's traditional allies in the Eastern bloc, including Russia and China, were also finding ways to accommodate and trade weapons with the apartheid state (Van Vuuren, 2017).

Finally, we have found evidence of at least four dozen other countries that acted as proxies for the big powers in providing the apartheid state with weapons. They were located in Africa, Asia, Europe and the Americas. In turn, they were matched by the eager assistance provided by fellow pariah states such as Israel, Argentina and Chile, whose authoritarian regimes or domestic policies made them fellow outcasts and natural allies of the apartheid regime. Support for apartheid South Africa relied on more than just racial solidarity: by the 1980s money was driving covert politics across the globe. 


\subsection{BUSTING THE MYTHS}

The apartheid states' secret economy and a network of international allies has for long been shielded and obscured by myths. These in turn have created a misleading narrative about the nature of apartheid and economic crime in that period which should be dispelled.

\subsubsection{Myth 1: Corruption is a Racial Phenomenon}

A powerful misconception, fuelled both by former NP leaders and persistent racism, is that corruption in South Africa is a phenomenon that is intrinsic to majority rule. It is the subtext of some criticism of the post-apartheid state. It is made more obvious by the singular focus on contemporary corruption in government with little reflection on the private sector where white South Africans are more prominent. The apartheid regime lied, bribed and broke every rule in the book to bust sanctions. The scale of these activities was so large that they should have been included in economic indicators at the time. These were not piecemeal activities. Instead, state capture was systemic.

To refer to white or black corruption is not only crude, but is simply incorrect: there is no basis in evidence to support a racial reading of corruption. Money does not know colour, as shown by the profile of people who assisted with arms sanctions-busting activities. While there was a predisposition to networks of white power, powerful people of all shades, religious beliefs and continents were drawn into aiding and abetting these crimes.

Our understanding of issues of economic crime the world over is still bedevilled by cultural relativism. The consequence of seeing such crimes, which are fundamentally crimes of human rights, as specific to cultural groups is that it shifts our attention away from powerful corrupt elite networks that claim a false cultural neutrality. The propensity for corruption relies on a mixture of secrecy and concentration of power. Apartheid is an excellent example of this. Nevertheless, countless other examples are evident, from New York's Wall Street to the Communist Party headquarters in Beijing.

One of the reasons that South Africa cannot afford to be caught in the bind of what the writer Songezo Zibi refers to as 'moral relativism' is that it entraps us (Zibi, 2014). It leaves us unable to confront contemporary corruption because the practice was largely unchecked during apartheid. This is argument is deployed with some effect by groupings who defend the interests of corporate and political elite (such as Jacob Zuma) who benefited from state capture. When this faction held the highest political office in the country, they never sought any genuine criminal accountability of past beneficiaries of economic crime. Their level of disinterest extended to a range of 
human rights violations under apartheid which were all ripe for investigation and prosecution. They however showed little interest in the matter and in some instances enabled efforts to suppress such prosecutions. Now that these political elites are scrutinised for their own alleged wrong doings the lack of prosecution of economic crimes of apartheid is expediently used as a tool of distraction.

\subsubsection{Myth 2: Apartheid South Africa was an Isolated State}

The sanctions period was known as 'isolation'. This was made tangible at the UN, in international forums and in areas such as sports and culture. Psychologically this was a powerful weapon that was used skilfully by the organised anti-apartheid movement across the globe. From Lagos to London and Washington DC, tens of thousands of activists organised themselves into local groups and rallied against apartheid. It was one of the most significant acts of international solidarity of the 20th century, driven by human rights groups, faith groups and international solidarity networks and a significant contributor to placing enormous pressure on the apartheid state.

While it significantly contributed to the regime's economic woes, it did not provide an existential threat. The apartheid security state under PW Botha used the threat of 'isolation' to its own advantage. As Hannah Arendt (1973) has argued, isolationism is an intrinsic element of totalitarian regimes. The NP could use this, through propaganda, to rally support while heaping on themselves the status of victim.

We need to separate reality from fiction. Isolation was the fiction, widely repeated for political ends. In reality, the apartheid state walked through open doors around the world and had direct diplomatic and economic links behind closed doors. It bought, sold and bartered with the heads of corporations, governments and intelligence agencies. An army of crafty middlemen made a mint of money out of helping to cut such deals. This is a reflection not of how the anti-apartheid movement was defeated, but of how conservative political groupings and their financial interests collude to undermine the work of democrats. Economic and strategic sanctions did little to visibly alter the lives of the white minority: they simply paid more tax. The banks lent money, the oil tankers kept arriving, and weapons systems and associated technology, though more expensive to procure, remained in abundant supply.

\subsubsection{Myth 3: Apartheid was Self-Sufficient}

Linked to the myth of self-isolation is the myth that in the late apartheid period, the South African state was a self-sufficient arms producer. It was not. It became expert at smuggling technology and expertise into the country and, in some instances, improving on this, before churning out the same goods under other names in its own factories. In other instances, container loads of key weapons were simply imported. 
This not only fuelled a war economy but became the driver for a conflict in which the military-industrial complex was deeply invested.

\subsubsection{Myth 4: Apartheid was Unprofitable}

While the oppressive apartheid project was unsustainable, it was very profitable for some and the South African casino economy of the 1970s and 1980s left a small elite group very wealthy. Money was extracted from the mines, the arms sector and state procurement. All were key to the fortunes made by a tiny elite within the golden circle. There were no doubt major factors which inhibited economic development. These included the debt crisis of the mid 1980s, political unrest, high public debt and spending on war, inflation and a host of other factors. However, for much of the $1980 \mathrm{~s}$ big business made massive profits from apartheid.

For the captains of industry to arrive, cap in hand, at the Truth and Reconciliation Commission (TRC) and argue, disingenuously, that they too were 'victims' of apartheid is an affront to the truth and an insult to the true victims of apartheid (Van Vuuren, 2017). The business submissions to the TRC were breathtaking in their brevity. No doubt acting on legal advice, many of the corporations and wealthy individuals admitted that apartheid was a crime but neglected to include any significant details of their direct or indirect complicity with the apartheid state. Where detail was included, it erred towards demanding absolution. The industry bosses such as Johann Rupert who were bold enough to appear at the hearings tended to shift the focus to their humble efforts in opposing apartheid and their corporate charity programmes. As the journalist Max du Preez noted, "Despite the many dark suits and striped shirts, one could at times be forgiven for thinking this was a meeting of Anti-Apartheid movements ... especially when powerful companies like Anglo and Barlow Rand claimed to have always opposed apartheid" (SABC, 2011).

\subsubsection{Myth 5: The Defeat of Apartheid was Inevitable}

An idea that has been popularised by some ANC leaders is that victory in 1994 was inevitable. Following this logic is that all concessions that were made were consciously done by the ANC as a calculated political choice. This has, in turn, led critics of the ANC to suggest that it sold out on the cheap to (white minority) capital.

This is a deeply ahistorical understanding of the country's recent history. The capitulation of the apartheid regime was by no means inevitable by the early 1990s. It was undoubtedly under immense internal and external pressure; however, the regime had developed a clandestine supply chain of weapons and was looking at going as far as building its own clandestine ports to deliver goods to foreign countries (Van 
Vuuren, 2017). We can speculate, but if the securocrats had prevailed, it is possible that the regime could have lasted for another ten or 20 years. It may have seen a much closer relationship with countries such as China, or isolationism protected by a nuclear shield as in the case of North Korea. However, the military could have very likely kept on fighting, resulting in the loss of tens of thousands more lives. This is not to detract from the struggle against apartheid, but to recognise how powerful the military machinery was that these women and men confronted.

It was this power that helped to secure the survival of this elite and its perpetuation in the post-apartheid period. The negotiation process was not a process of surrender. It was a process of give and take. The power of these groups and the potential they had at the time to wreak havoc by using their military and economic might should not be underestimated.

\subsubsection{Myth 6: We Cannot Undo this Wrong}

Truth telling and justice are essential components for lasting peace. It is crucial that we continue to unpick the open secrets of our recent past. They inevitably define part of who we are as a country and the factors that represent obstacles in any quest to achieve meaningful social justice. The crimes of profit, just like those of murder, deserve to be challenged, and we can use advocacy and the law to achieve this. There are opportunities in law that should allow us to address some of these issues if there is the political will to do so. Consider the breakthrough in corporate accountability in 2016 when the South Gauteng High Court ruled that 500000 miners could bring a class action claim against the country's gold mines. This after almost a century during which far too little precaution was taken to prevent workers from contracting silicosis and TB, which in many instances have shortened their lives. The judgment is important in terms of our understanding of corporate accountability and of profittaking at human expense (Van Vuuren, 2017).

More recently the work of the Zondo Commission in South Africa can be viewed as an example of truth telling intended to benefit justice for the extensive crimes of state capture in South Africa. While the commission has shown a rather lacklustre approach to calling CEO's and Directors of corporations implicated in state capture to account, it has seen expert witnesses provide meticulous detail of money flows and submissions from civil society which fully expose the role of corporations in state capture.

South Africa is also not the only country attempting to clear up the legacy of economic crimes that are linked to human rights violations, and the experience of other countries shows that it is not only never too late, but it is possible. Important 
recent examples of this is the establishment of a Truth and Dignity Commission in Tunisia which was specifically tasked with also investigating economic crime which had contributed to human rights violation in the years preceding the Arab Spring. Another important example is a recent Gambian commission of inquiry to investigate ex-dictator Yahya Jammeh's corruption. It has also identified stolen assets which can be used for reparations in the Gambia (Carranza, 2020).

\subsubsection{Myth 7: Freedom Signalled a Clean Break with the Past}

Everything did not change overnight in newly democratic South Africa. Consider how we continue to battle with the increasing problems of unemployment and inequality. The corporations, middlemen, politicians and intelligence agencies that assisted the apartheid state also did not disappear off the scene for good.

This is most evident in the corrupt multi-billion-dollar arms deal of the Mbeki era. A number of the leading arms, oil and commodity sanctions busters played a role in this. In some instances, tenders were incorrectly and corruptly awarded to the same companies that had kept apartheid alive. If we had investigated these issues at the time - or if intelligence authorities spent time in the state archives - they might have done more to insulate the state from doing business with such corrupt entities. Within the private sector, these tendencies to subvert and undermine the rule of law could be arrested by new corporate governance standards, but they could not be erased overnight.

There was therefore no clean break with our past after 1994: the corrupt networks would soon be back. On their return, they were more nuanced in their approach and deferential to the new elite, who rapidly welcomed them in with a familiar, warm South African embrace. The old and the new were quickly intertwined and found in each other partners and protectors.

In 2018, a group of civil society organisations, with Open Secrets acting as the Secretariat, convened the First Peoples Tribunal on Economic Crime in South Africa. With a focus on economic crime in the arms trade (between 1977 and 2017) evidence was heard by a panel of adjudicators including former Constitutional Court Justice Zac Yacoob and UN Human Rights Commission Chair Justice Navi Pillay. After five days of hearings and a numbers of months granted to the implicated parties to respond to evidence of wrongdoing, one of the trenchant findings by the panel was that the Tribunal had presented strong evidence that the failure to address the economic crimes and sanctions-busting activity from the apartheid era which in part explained the illicit activities later in the Arms Deal and in contemporary state capture (The People's Tribunal on Economic Crime, 2018). In other words, the panel argued that the continuities are obvious should we care to take note. 
Squaring off with this past, is not only a matter of truth telling, but should also be about justice as a remedy for impunity. Undoubtedly, one of the most important ongoing prosecutions in South Africa involves the French arms company Thales and its payment of bribes to Jacob Zuma. These bribes were alleged to not only shore up contracts for Thales but ensure that they would not be subsequently troubled by investigations by the South African state into alleged criminality. Thales, in an earlier guise as Thomson CSF, had been one of many key French arms allies of the apartheid regime - yet slid almost seamlessly into its new role as a benefactor of the politicians the apartheid regime had imprisoned during the freedom struggle. This alleged corrupt relationship between Zuma and Thales and the looming threat of a criminal prosecution starting in 2005, spurred Zuma and his network of allies into dismantling key anti-corruption institutions. In so doing, the king would be made untouchable from prosecution and so too would be his kingmakers in the arms trade. However, this fightback against accountability became about more than just the legal troubles of Zuma and Thales. It set in motion a process that rolled out a long red welcome mat for the state capture cabal. Once the key anti-corruption agencies had been closed down and the National Prosecutions Authority fundamentally weakened, it was open season for a new group of allies in the Guptas, their political middlemen and a band of corporate enablers in Sandton, London, Hong Kong and elsewhere.

\subsection{CONCLUSION}

South Africa's obsession with its own exceptionalism has created a blinkered world view which inhibits us from identifying how we mimic political and economic developments in other states. However, it has also blinkered the country from seeing how different domestic crises are in fact part of a much longer trajectory. There is a golden thread of plunder and which weaves it way from apartheid economic crimes, through to the corruption riddled arms deal steered by Thabo Mbeki and ultimately state capture of the Zuma years which continues to fester in our politics. The underlying reasons for this are manyfold and are linked to the structure of the South African economy, the dominance of deep state actors in decision-making and income and ownership inequality. Nearly three decades of freedom have failed to deliver leaders who have the vision and commitment to constitutional values to fundamentally alter these patterns of behaviour. We have a political and corporate class in South Africa which mimics some of the worst behaviour we have shown to be evident in South Africa's earliest state capture which preceded the country's first free election in 1994.

Justice for past crimes is therefore a necessity if we are to break the cycles of repetition and the stranglehold that powerful global networks and their local frontmen have on democracy in South Africa. The lessons of why we cannot allow state capture networks 
to succeed do not lie in some well of wisdom and moral authority or the belief that the governing ANC can return to a state of innocence as some would suggest. The original sin of apartheid and accompanying economic crime has long tainted our politics, while we cannot undo all the harm this has created, future generations should not have to endure the burden of repetition. 


\section{References}

Arendt, H. (1973) The origins of totalitarianism. New York: Houghton Mifflin Harcourt.

Carranza, R. (2020) 'Truth, Accountability, and Asset Recovery: How Transitional Justice Can Fight Corruption, International Center for Transitional Justice August. [Online]. https:// bit.ly/3xzOyyS (Accessed 4 May 2021).

Holden, P. \& Van Vuuren, H. (2011) The devil in the detail: how the arms deal changed everything. Cape Town: Jonathan Ball Publishers.

Lodge, T. (1998) 'Political corruption in South Africa', African Affairs, 97(387):157-187. https://doi.org/10.1093/oxfordjournals. afrafa007924
Lodge, T. (2014) 'Neo-patrimonial politics in the ANC', African Affairs, 113(450):1-23. https://doi.org/10.1093/afraf/adt069

SABC (2011) 'TRC Special Report. Episode 74, Part 03, 16 November 1997, YouTube. [Online]. https://bit.ly/3fGtyjV (Accessed 4 May 2021).

The People's Tribunal on Economic Crime (2018) Final Report of the People's Tribunal on Economic Crime. [Online]. https://bit.ly/ 2TZjMBJ (Accessed 6 July 2020).

Van Vuuren, H. (2017) Apartheid Guns and Money: A tale of profit. Johannesburg: Jacana Media.

Zibi, S. (2014) Raising the bar: Hope and renewal in South Africa. Johannesburg: Picador Africa. 



\section{APPENDIX}

\begin{tabular}{|c|c|c|c|c|}
\hline $\begin{array}{l}\text { Case Study } \\
\text { in State } \\
\text { Capture }\end{array}$ & Status & Summary Description & $\begin{array}{l}\text { Investigation } \\
\text { Body / } \\
\text { Source of } \\
\text { Evidence }\end{array}$ & $\begin{array}{l}\text { Government } \\
\text { Entity } \\
\text { Implicated }\end{array}$ \\
\hline \multicolumn{5}{|c|}{ Scandals Connected to Jacob Zuma, Guptas, Other Key Networks and ANC Politics } \\
\hline $\begin{array}{l}\text { The State } \\
\text { of Capture } \\
\text { report - } \\
\text { focuses } \\
\text { on Guptas' } \\
\text { relationship } \\
\text { with Jacob } \\
\text { Zuma and } \\
\text { their alleged } \\
\text { influence on } \\
\text { the affairs } \\
\text { of state }\end{array}$ & $\begin{array}{l}\text { First complaint } \\
\text { was received } \\
\text { in March } 2016 \\
\text { and the report } \\
\text { was released in } \\
\text { November } 2016 .\end{array}$ & $\begin{array}{l}\text { Investigation into complaints of alleged improper } \\
\text { and unethical conduct by the President and } \\
\text { other State Functionaries, relating to alleged } \\
\text { improper relationships and involvement of the } \\
\text { Gupta Family in the removal and appointment } \\
\text { of Ministers and Directors of State-Owned } \\
\text { Enterprises (SOEs), resulting in improper and } \\
\text { possibly corrupt award of State Contracts and } \\
\text { Benefits to the Gupta Family's Businesses. } \\
\text { The report details numerous allegations of } \\
\text { the Guptas' involvement in affairs of the state } \\
\text { and their irregular activities that enable rent } \\
\text { extraction. The findings were not conclusive } \\
\text { and the remedial action was to establish a } \\
\text { commission of inquiry into state capture (to } \\
\text { be appointed by the President, but with a } \\
\text { judge selected by the Chief Justice). Litigation } \\
\text { endeavoured to delay or prohibit the report's } \\
\text { release and implementation of remedial actions, } \\
\text { but failed, and the commission was established } \\
\text { in } 2018 \text {. }\end{array}$ & $\begin{array}{l}\text { - Public } \\
\text { Protector, } \\
\text { followed by } \\
\text { litigation }\end{array}$ & $\begin{array}{l}\text { - GCIS (The } \\
\text { New Age) } \\
\text { - Eskom } \\
\text { (Optimum) } \\
\text { - Transnet } \\
\text { (Regiments/ } \\
\text { Trillian) } \\
\text { - Denel } \\
\text { - SAA (The } \\
\text { New Age) } \\
\text { - SABC (The } \\
\text { New Age) } \\
\text { - Department of } \\
\text { Finance } \\
\text { - Transport } \\
\text { (SAA) } \\
\text { - Communica- } \\
\text { tions (SABC } \\
\text { \& GCIS) }\end{array}$ \\
\hline $\begin{array}{l}\text { Zondo } \\
\text { Commission }\end{array}$ & $\begin{array}{l}\text { Established } \\
\text { in 2018, with } \\
\text { anticipated } \\
\text { conclusion being } \\
\text { the end of } 2021 .\end{array}$ & $\begin{array}{l}\text { Formally titled the Judicial Commission of } \\
\text { Inquiry into Allegations of State Capture, } \\
\text { Corruption and Fraud in the Public Sector } \\
\text { including Organs of State, the Commission } \\
\text { was promulgated by then President Zuma in } \\
\text { response to the remedial actions as outlined in } \\
\text { the Public Protector's State of Capture report. } \\
\text { As of June } 2021 \text {, the Commission that started } \\
\text { in August } 2018 \text { has held more than } 418 \text { days } \\
\text { of hearings of over } 330 \text { testimonies (generating } \\
\text { over } 71000 \text { pages of transcript). The inquiry's } \\
\text { terms of reference were expansive and, as } \\
\text { such, the scope of investigations went beyond } \\
\text { merely looking into the Gupta-related cases, } \\
\text { covering other networks (e.g., Bosasa) as well } \\
\text { as other government institutions (e.g., role } \\
\text { of Parliament). }\end{array}$ & $\begin{array}{l}\text { - Zondo } \\
\text { Commission }\end{array}$ & $\begin{array}{l}\text { Various } \\
\text { work-streams } \\
\text { covering } \\
\text { inter alia: } \\
\text { - SOEs } \\
\text { (Eskom, } \\
\text { Transnet, } \\
\text { Denel, SAA) } \\
\text { - Free State } \\
\quad \text { Provincial } \\
\text { Government } \\
\text { - Bosasa } \\
\text { - SARS } \\
\text { - Law } \\
\text { enforcement } \\
\text { - State Security } \\
\text { Agency (SSA) } \\
\text { - The New Age } \\
\text { \& ANN7 } \\
\text { - Role of } \\
\text { Parliament } \\
\text { and ANC }\end{array}$ \\
\hline
\end{tabular}




\begin{tabular}{|c|c|c|c|c|}
\hline $\begin{array}{l}\text { Case Study } \\
\text { in State } \\
\text { Capture }\end{array}$ & Status & Summary Description & $\begin{array}{l}\text { Investigation } \\
\text { Body / } \\
\text { Source of } \\
\text { Evidence }\end{array}$ & $\begin{array}{l}\text { Government } \\
\text { Entity } \\
\text { Implicated }\end{array}$ \\
\hline \multicolumn{5}{|c|}{ Scandals Connected to Jacob Zuma, Guptas, Other Key Networks and ANC Politics } \\
\hline Bosasa & $\begin{array}{l}\text { Dating back to a } \\
2009 \text { SIU report. } \\
\text { Investigations and } \\
\text { various litigations } \\
\text { are ongoing. }\end{array}$ & $\begin{array}{l}\text { In 2019, former Bosasa C00, Anglo Agrizzi, } \\
\text { testified at the Zondo Commission, detailing } \\
\text { the acts and long history of corruption between } \\
\text { various Bosasa companies predominantly } \\
\text { owned by Gavin Watson, and numerous } \\
\text { government entities/departments. The } \\
\text { testimony of Agrizzi (and other former Bosasa } \\
\text { employees) corroborated the findings of a } \\
2009 \text { SIU investigation that alleged corruption } \\
\text { in several contracts Bosasa had with the } \\
\text { Department of Correctional Services. Criminal } \\
\text { court proceedings have been initiated based } \\
\text { on the } 2009 \text { SIU investigation, along with new } \\
\text { investigations initiated by SARS and other law } \\
\text { enforcement entities. }\end{array}$ & $\begin{array}{l}\text { - Special } \\
\text { Investi- } \\
\text { gation } \\
\text { Unit (SIU) } \\
\text { - Zondo } \\
\text { Commission }\end{array}$ & $\begin{array}{l}\text { - Department of } \\
\text { Correctional } \\
\text { Services } \\
\text { - Department of } \\
\text { Justice } \\
\text { - Department of } \\
\text { Home Affairs } \\
\text { - Department of } \\
\text { Transport } \\
\text { - Various SOEs } \\
\text { (e.g., SAPO, } \\
\text { ACSA) } \\
\text { - National } \\
\text { Prosecuting } \\
\text { Authority } \\
\text { (NPA) } \\
\text { - Members of } \\
\text { Parliament }\end{array}$ \\
\hline Arms Deal & $\begin{array}{l}\text { Various } \\
\text { investigations and } \\
\text { sources, dating } \\
\text { back to 1990s. } \\
\text { Most significant } \\
\text { source being } \\
\text { through Seriti } \\
\text { Commission. } \\
\text { Corruption case } \\
\text { against Zuma is } \\
\text { ongoing. }\end{array}$ & $\begin{array}{l}\text { Commission of Inquiry into allegations of fraud, } \\
\text { corruption, impropriety, or irregularity in the } \\
\text { Strategic Defence Procurement Packages } \\
\text { (SDPP). Various court cases related to } \\
\text { allegations of corruption against Jacob Zuma. } \\
\text { On Monday, } 24 \text { October 2011, the President } \\
\text { announced the Commission chaired by Judge } \\
\text { Seriti. The findings of the Commission were that } \\
\text { there was "no evidence" of corruption, but this } \\
\text { is seen by many to have been a whitewash. The } \\
\text { report was taken on review and set aside in } \\
\text { August } 2019 \text {. The corruption case against Zuma } \\
\text { is ongoing before the courts. }\end{array}$ & $\begin{array}{l}\text { - Seriti } \\
\text { Commission } \\
\text { - Various } \\
\text { court cases }\end{array}$ & $\begin{array}{l}\text { Initially: } \\
\text { - South African } \\
\text { National } \\
\text { Defence } \\
\text { Force } \\
\text { - Members of } \\
\text { Parliament } \\
\text { Allegations also } \\
\text { involve: } \\
\text { - NPA } \\
\text { - SSA }\end{array}$ \\
\hline $\begin{array}{l}\text { Nkandla } \\
\text { Security } \\
\text { Upgrades }\end{array}$ & $\begin{array}{l}\text { Investigation } \\
\text { started in } \\
\text { November } 2012 . \\
\text { Report on } \\
\text { investigation } \\
\text { was released in } \\
\text { March } 2014 .\end{array}$ & $\begin{array}{l}\text { Report on security upgrades to President } \\
\text { Zuma's homestead in Nkandla. The investigation } \\
\text { found that the President unduly benefited from } \\
\text { the upgrades and as part of remedial actions } \\
\text { the President was required to pay back a portion } \\
\text { of the costs of the upgrades. Zuma instructed } \\
\text { that SAPS undertake their own investigation, } \\
\text { which sought to rationalise the expenses (fire- } \\
\text { pool report). Parliament accepted this alternative } \\
\text { report, but major court cases followed, } \\
\text { ultimately declaring that the Public Protector's } \\
\text { remedial actions are binding. President and } \\
\text { Parliament failed to uphold the Constitution. } \\
\text { President ordered to "pay back the money". }\end{array}$ & $\begin{array}{l}\text { - Public } \\
\text { Protector's } \\
\text { Secured } \\
\text { in Comfort } \\
\text { report, } \\
\text { followed by } \\
\text { litigation }\end{array}$ & 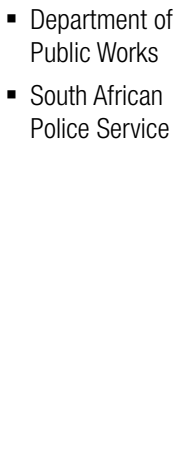 \\
\hline
\end{tabular}




\begin{tabular}{|c|c|c|c|c|}
\hline $\begin{array}{l}\text { Case Study } \\
\text { in State } \\
\text { Capture }\end{array}$ & Status & Summary Description & $\begin{array}{l}\text { Investigation } \\
\text { Body / } \\
\text { Source of } \\
\text { Evidence }\end{array}$ & $\begin{array}{l}\text { Government } \\
\text { Entity } \\
\text { Implicated }\end{array}$ \\
\hline \multicolumn{5}{|c|}{ Scandals Connected to Jacob Zuma, Guptas, Other Key Networks and ANC Politics } \\
\hline $\begin{array}{l}\text { Private } \\
\text { Aircraft } \\
\text { Landing at } \\
\text { Waterkloof } \\
\text { Airforce Base } \\
\text { and Gupta } \\
\text { Sun City } \\
\text { Wedding }\end{array}$ & May 2013. & $\begin{array}{l}\text { In 2013, justice, crime prevention, and } \\
\text { security cluster (JCPS) - a cabinet structure } \\
\text { composed of various ministries - undertook an } \\
\text { investigation into the Landing of a Commercial } \\
\text { aircraft at Air Force Base Waterkloof (report } \\
\text { titled the same). The investigation revealed that } \\
\text { the Guptas initially tried to organise a special } \\
\text { landing at OR Tambo International Airport, but } \\
\text { was turned down. They then approached the } \\
\text { Indian High Commission who re-designated the } \\
\text { wedding entourage as an official delegation to } \\
\text { secure a landing at the Waterkloof base. The } \\
\text { wedding held at Sun City was attended by a } \\
\text { number of high-profile ANC politicians and was } \\
\text { paid for in part by moneys looted from the Vrede } \\
\text { Dairy Farm project. }\end{array}$ & $\begin{array}{l}\text { - Report by } \\
\text { JPCS } \\
\text { - Zondo } \\
\text { Commission }\end{array}$ & $\begin{array}{l}\text { - Department of } \\
\text { International } \\
\text { Relations and } \\
\text { Cooperation } \\
\text { (DIRCO) } \\
\text { - Department of } \\
\text { Defence } \\
\text { - Department of } \\
\text { Transport }\end{array}$ \\
\hline $\begin{array}{l}\text { Free State } \\
\text { Provincial } \\
\text { Capture, } \\
\text { includes } \\
\text { Vrede Dairy } \\
\text { Farm and } \\
\text { Asbestos } \\
\text { Contracts }\end{array}$ & Ongoing. & $\begin{array}{l}\text { The Vrede Dairy Farm project was initiated } \\
\text { by the Free State Provincial Government as a } \\
\text { development project, however, in partnering with } \\
\text { a Gupta-linked company Estina, government } \\
\text { funds were looted. In 2018, the Public } \\
\text { Protector released a report on their } 2018 \\
\text { investigation, but it was taken on review and } \\
\text { set aside by the courts. The second part of the } \\
\text { investigation is yet to be finalised. The NPA } \\
\text { laid criminal charges against Gupta associates } \\
\text { and implicated government officials. Court } \\
\text { proceedings are ongoing. } \\
\text { Significant testimony and evidence have been } \\
\text { presented at the Zondo Commission regarding } \\
\text { the Vrede Farm case, as well as the asbestos } \\
\text { inspection project (criminal proceedings are also } \\
\text { underway). Both projects implicate high-profile } \\
\text { politicians and senior officials manipulating } \\
\text { government process. }\end{array}$ & $\begin{array}{l}\text { - } \text { Public } \\
\text { Protector } \\
\text { reports } \\
\text { - Zondo } \\
\text { Commission } \\
\text { - Various } \\
\text { court cases }\end{array}$ & $\begin{array}{l}\text { - Free State } \\
\text { Provincial } \\
\text { Government }\end{array}$ \\
\hline $\begin{array}{l}\text { Irregular } \\
\text { removal of } \\
\text { National } \\
\text { Director } \\
\text { of Public } \\
\text { Prosecutions } \\
\text { (NDPP), } \\
\text { Mxolisi } \\
\text { Nxasana }\end{array}$ & $\begin{array}{l}\text { Inquiry instituted } \\
\text { in February } 2015, \\
\text { but was cancelled } \\
\text { in May } 2015 . \\
\text { This triggers the } \\
\text { Constitutional Court } \\
\text { cases that followed. }\end{array}$ & $\begin{array}{l}\text { Inquiry into the fitness of Mxolisi Nxasana to } \\
\text { hold office as NDPP. The Inquiry was cancelled } \\
\text { after Zuma "agreed to let Nxasana resign". He } \\
\text { was paid R17m - the balance of his ten-year } \\
\text { contract. Court cases followed detailing the } \\
\text { abuse of the presidency powers by Zuma. } \\
\text { Ultimately, Nxasana was ordered to repay } \\
\text { R17m and Zuma's appointed replacement, } \\
\text { Shawn Abrahams, was ordered to vacate office. } \\
\text { Constitutional Court found Zuma's actions to } \\
\text { be an abuse of power and in breach of his } \\
\text { constitutional obligations. }\end{array}$ & $\begin{array}{l}\text { - Cassim } \\
\text { Inquiry into } \\
\text { fitness of } \\
\text { Mxolisi } \\
\text { Nxasana to } \\
\text { hold office } \\
\text { of NDPP } \\
\text { initiated } \\
\text { by Zuma, } \\
\text { followed by } \\
\text { litigation }\end{array}$ & $\begin{array}{l}\text { - National } \\
\text { Prosecution } \\
\text { Authority }\end{array}$ \\
\hline $\begin{array}{l}\text { Political } \\
\text { killings in } \\
\text { KZN }\end{array}$ & $\begin{array}{l}\text { Established in } \\
\text { October } 2016 . \text { The } \\
\text { report was released } \\
\text { in May } 2018 .\end{array}$ & $\begin{array}{l}\text { On } 28 \text { October 2016, the Premier of the } \\
\text { Province of KwaZulu-Natal established a } \\
\text { Commission of Enquiry into the Underlying } \\
\text { Causes of the Murder of Politicians in KwaZulu- } \\
\text { Natal (KZN). }\end{array}$ & $\begin{array}{l}\text { - Moerane } \\
\text { Commission } \\
\text { of Enquiry }\end{array}$ & $\begin{array}{l}\text { - KZN Provincial } \\
\text { Government } \\
\text { - KZN Local } \\
\text { Governments }\end{array}$ \\
\hline
\end{tabular}




\begin{tabular}{|c|c|c|c|c|}
\hline $\begin{array}{l}\text { Case Study } \\
\text { in State } \\
\text { Capture }\end{array}$ & Status & Summary Description & $\begin{array}{l}\text { Investigation } \\
\text { Body / } \\
\text { Source of } \\
\text { Evidence } \\
\end{array}$ & $\begin{array}{l}\text { Government } \\
\text { Entity } \\
\text { Implicated }\end{array}$ \\
\hline \multicolumn{5}{|c|}{ Scandals Connected to Jacob Zuma, Guptas, Other Key Networks and ANC Politics } \\
\hline \multicolumn{5}{|c|}{ State Capture of State-Owned Enterprises and Government Departments } \\
\hline $\begin{array}{l}\text { Interference } \\
\text { in operations } \\
\text { at the SABC }\end{array}$ & $\begin{array}{l}\text { The Ad Hoc } \\
\text { Committee was } \\
\text { established in } \\
\text { November } 2016 \\
\text { and final report } \\
\text { was tabled on } \\
24 \text { February } 2017 .\end{array}$ & $\begin{array}{l}\text { Parliamentary Ad Hoc Committee on the } \\
\text { SABC Board Inquiry into mismanagement and } \\
\text { interference in SABC operations. Findings } \\
\text { include evidence of Minister Faith Muthambi's } \\
\text { interference in the organisation and editorial } \\
\text { interference, in the firing of SABC } 8 \text { who } \\
\text { protested censorship of the national broadcaster } \\
\text { (on instruction from COO Hlaudi Motsoeneng). It } \\
\text { should be noted that the inquiry was preceded } \\
\text { by an investigation by the Public Protector. } \\
\text { Details are contained in the } 2014 \text { report titled } \\
\text { When Governance and Ethics Fail. }\end{array}$ & $\begin{array}{l}\text { - Parliamen- } \\
\text { tary Inquiry } \\
\text { - Preceded by } \\
\text { an investi- } \\
\text { gation by } \\
\text { the Public } \\
\text { Protector }\end{array}$ & $\begin{array}{l}\text { - SABC } \\
\text { (Department } \\
\text { of Communi- } \\
\text { cation) }\end{array}$ \\
\hline \multirow[t]{2}{*}{$\begin{array}{l}\text { Passenger } \\
\text { Rail Agency } \\
\text { of South } \\
\text { Africa } \\
\text { (PRASA) }\end{array}$} & $\begin{array}{l}\text { Complaints were } \\
\text { lodged in } 2012 \\
\text { and the report } \\
\text { was released in } \\
\text { August } 2015 .\end{array}$ & $\begin{array}{l}\text { Several cases of "mismanagement and } \\
\text { irregularities" regarding various contracts. } \\
\text { Lucky Montana was CEO at the time. One of } \\
\text { the remedial actions stipulated that National } \\
\text { Treasury was to investigate all PRASA contracts } \\
\text { from } 2012 \text { onwards with a value of R10 million } \\
\text { or more. National Treasury implemented the } \\
\text { remedial action which resulted in several } \\
\text { investigations, the details of which were leaked } \\
\text { to the public. }\end{array}$ & $\begin{array}{l}\text { - Public } \\
\text { Protector's } \\
\text { Derailed } \\
\text { report on } \\
\text { PRASA } \\
\text { - Numerous } \\
\text { investiga- } \\
\text { tions }\end{array}$ & $\begin{array}{l}\text { - PRASA } \\
\text { - Department of } \\
\text { Transport }\end{array}$ \\
\hline & $\begin{array}{l}\text { In June } 2017, \\
\text { Parliament directed } \\
4 \text { committees to } \\
\text { investigate state } \\
\text { capture. Committee } \\
\text { hearings were not } \\
\text { completed. }\end{array}$ & $\begin{array}{l}\text { In terms of the parliamentary directive, the } \\
\text { Portfolio Committee on Transport was requested } \\
\text { to establish an Inquiry into State Capture at } \\
\text { PRASA. However, the Portfolio Committee noted } \\
\text { that PRASA was not mentioned in the Public } \\
\text { Protector's State of Capture report and decided } \\
\text { they would focus on the various investigation } \\
\text { reports produced for National Treasury (as } \\
\text { recommended in Derailed report). }\end{array}$ & $\begin{array}{l}\text { - Portfolio } \\
\text { Committee } \\
\text { on Transport }\end{array}$ & $\begin{array}{l}\text { - PRASA } \\
\text { - Department of } \\
\text { Transport }\end{array}$ \\
\hline $\begin{array}{l}\text { Eskom } \\
\text { Inquiry into } \\
\text { State Capture }\end{array}$ & $\begin{array}{l}\text { In June } 2017 \text {, } \\
\text { Parliament directed } \\
4 \text { committees } \\
\text { to investigate } \\
\text { state capture. } \\
\text { Public Enterprises } \\
\text { Committee } \\
\text { report on Eskom } \\
\text { was released in } \\
\text { November } 2018 .\end{array}$ & $\begin{array}{l}\text { Extensive hearings were held by the Committee } \\
\text { detailing much of the evidence presented in } \\
\text { the Public Protector's report. The Committee } \\
\text { presented recommendations and compiled } \\
\text { a final report detailing their findings. These } \\
\text { included findings that Ministers Lynne Brown } \\
\text { and Malusi Gigaba were negligent and had to } \\
\text { be held accountable. Also recommended that } \\
\text { criminal investigations be undertaken against } \\
\text { the relevant Eskom executives. }\end{array}$ & $\begin{array}{l}\text { - Parliamen- } \\
\text { tary Inquiry }\end{array}$ & $\begin{array}{l}\text { - Eskom } \\
\text { - Department } \\
\text { of Public } \\
\text { Enterprises }\end{array}$ \\
\hline $\begin{array}{l}\text { Nugent } \\
\text { Commission } \\
\text { - SARS } \\
\text { Inquiry }\end{array}$ & $\begin{array}{l}\text { The Inquiry was } \\
\text { constituted on } \\
24 \text { May } 2018 \text { and } \\
\text { the final report } \\
\text { was released in } \\
\text { December } 2018 .\end{array}$ & $\begin{array}{l}\text { Commission of Inquiry into tax administration } \\
\text { and governance by South African Revenue } \\
\text { Service (SARS). Tom Moyane was fired based on } \\
\text { the interim report released in September } 2018 . \\
\text { The inquiry found that Moyane, with the help of } \\
\text { consultancy company Bain, had implemented } \\
\text { restructuring of the organisation, resulting in } \\
\text { gross mismanagement and erosion of SARS. } \\
\text { Moyane motivated the restructuring based on } \\
\text { the "rogue unit" narrative that has been the } \\
\text { subject of several other debunked investigations } \\
\text { and the subject of much litigation. }\end{array}$ & $\begin{array}{l}\text { - Judicial } \\
\text { Commission } \\
\text { of Inquiry } \\
\text { - Court cases } \\
\text { around the } \\
\text { "rogue unit" } \\
\text { narrative }\end{array}$ & $\begin{array}{l}\text { - SARS } \\
\text { (National } \\
\text { Treasury) }\end{array}$ \\
\hline
\end{tabular}




\begin{tabular}{|c|c|c|c|c|}
\hline $\begin{array}{l}\text { Case Study } \\
\text { in State } \\
\text { Capture }\end{array}$ & Status & Summary Description & $\begin{array}{l}\text { Investigation } \\
\text { Body / } \\
\text { Source of } \\
\text { Evidence }\end{array}$ & $\begin{array}{l}\text { Government } \\
\text { Entity } \\
\text { Implicated }\end{array}$ \\
\hline \multicolumn{5}{|c|}{ Scandals Connected to Jacob Zuma, Guptas, Other Key Networks and ANC Politics } \\
\hline \multicolumn{5}{|c|}{ State Capture of State-Owned Enterprises and Government Departments } \\
\hline $\begin{array}{l}\text { Commission } \\
\text { of Inquiry } \\
\text { into Public } \\
\text { Investment } \\
\text { Corporation } \\
\text { (PIC) }\end{array}$ & $\begin{array}{l}\text { In October } 2018 \text {, } \\
\text { the Commission } \\
\text { was constituted, } \\
\text { and the final report } \\
\text { was released in } \\
\text { March } 2020 .\end{array}$ & $\begin{array}{l}\text { Commission of Inquiry into allegations of } \\
\text { impropriety regarding Public Investment } \\
\text { Corporation (PIC). There were extensive hearings } \\
\text { on various 'dodgy' deals the PIC entered } \\
\text { into and details of political and executive } \\
\text { interference in the operations and decision- } \\
\text { making processes of the investment agency. }\end{array}$ & $\begin{array}{l}\text { - Judicial } \\
\text { Commission } \\
\text { of Inquiry }\end{array}$ & $\begin{array}{l}\text { - PIC (National } \\
\text { Treasury) }\end{array}$ \\
\hline $\begin{array}{l}\text { South African } \\
\text { Social } \\
\text { Security } \\
\text { Agency } \\
\text { (SASSA) }\end{array}$ & $\begin{array}{l}\text { Various } \\
\text { Constitutional Court } \\
\text { cases from } 2011 \\
\text { to } 2018 \text { resulted } \\
\text { in removal of CPS } \\
\text { as service provider } \\
\text { to SASSA. }\end{array}$ & $\begin{array}{l}\text { In 2014, South African Social Security Agency's } \\
\text { (SASSA) } 2012 \text { contract with CPS was found } \\
\text { to be irregular and invalid, however, due to the } \\
\text { importance of ensuring beneficiaries received } \\
\text { grants, CPS continued to be the service } \\
\text { providers until } 2018 \text {. Following a March } 2017 \\
\text { ruling, the Constitutional Court instituted a } \\
\text { Section } 38 \text { Inquiry into Minister Bathabile } \\
\text { Dlamini's personal liability for the narrowly } \\
\text { averted grant payment crisis. }\end{array}$ & $\begin{array}{l}\text { Primary } \\
\text { sources: } \\
\text { - AllPay court } \\
\text { case } \\
\text { - Black Sash } \\
\text { court case }\end{array}$ & - SASSA \\
\hline $\begin{array}{l}\text { South African } \\
\text { Airways (SAA) } \\
\text { and SAA } \\
\text { Technical }\end{array}$ & $\begin{array}{l}\text { Court case } \\
\text { to have Dudu } \\
\text { Myeni declared a } \\
\text { delinquent director } \\
\text { was launched } \\
\text { in } 2017 .\end{array}$ & $\begin{array}{l}\text { Court case was launched in } 2017 \text { by Outa and } \\
\text { the SAA Pilots' Association (SAAPA) to declare } \\
\text { Myeni a delinquent director in terms of the } \\
\text { Companies Act, based on her actions while she } \\
\text { was chairperson of the SAA Board. In 2020, the } \\
\text { High Court declared Myeni a delinquent director } \\
\text { for life. A significant amount of new evidence } \\
\text { also emerged through the Zondo Commission, } \\
\text { outlining how the operations at SAA were } \\
\text { undermined and how Myeni and others abused } \\
\text { their positions of authority. }\end{array}$ & $\begin{array}{l}\text { - Court } \\
\text { papers } \\
\text { - Zondo } \\
\text { Commission }\end{array}$ & $\begin{array}{l}\text { - SAA } \\
\text { - SAA Technical }\end{array}$ \\
\hline $\begin{array}{l}\text { Gupta Family } \\
\text { Naturalisation }\end{array}$ & $\begin{array}{l}\text { In June } 2017, \\
\text { Parliament directed } \\
4 \text { committees to } \\
\text { investigate state } \\
\text { capture. Final } \\
\text { report was tabled } \\
14 \text { March } 2019 .\end{array}$ & $\begin{array}{l}\text { Portfolio Committee on Home Affairs Inquiry into } \\
\text { the Gupta Family Naturalisation was established } \\
\text { in terms of the Parliamentary directive. Hearings } \\
\text { formally started on } 12 \text { September 2018. Final } \\
\text { report was tabled on } 14 \text { March 2019. Questions } \\
\text { were raised around contracts with Visa } \\
\text { Facilitation Services. This matter is ongoing as } \\
\text { of December } 2020 \text {. }\end{array}$ & $\begin{array}{l}\text { - Portfolio } \\
\text { Committee } \\
\text { on Home } \\
\text { Affairs }\end{array}$ & $\begin{array}{l}\text { - Department of } \\
\text { Home Affairs }\end{array}$ \\
\hline $\begin{array}{l}\text { Inquiry into } \\
\text { State Capture } \\
\text { related to } \\
\text { Gupta-owned } \\
\text { mines }\end{array}$ & $\begin{array}{l}\text { In June } 2017, \\
\text { Parliament directed } \\
4 \text { committees } \\
\text { to investigate } \\
\text { state capture. }\end{array}$ & $\begin{array}{l}\text { Though the Committee drafted a term of } \\
\text { reference for the Inquiry, the activities of holding } \\
\text { hearings and consolidating the evidence never } \\
\text { materialised beyond questions being put to then } \\
\text { Minister Zwane. }\end{array}$ & $\begin{array}{l}\text { - Portfolio } \\
\text { Committee } \\
\text { on Mineral } \\
\text { Resources }\end{array}$ & $\begin{array}{l}\text { - Department } \\
\text { of Mineral } \\
\text { Resources }\end{array}$ \\
\hline
\end{tabular}




\begin{tabular}{|c|c|c|c|c|}
\hline $\begin{array}{l}\text { Case Study } \\
\text { in State } \\
\text { Capture }\end{array}$ & Status & Summary Description & $\begin{array}{l}\text { Investigation } \\
\text { Body / } \\
\text { Source of } \\
\text { Evidence }\end{array}$ & $\begin{array}{l}\text { Government } \\
\text { Entity } \\
\text { Implicated }\end{array}$ \\
\hline \multicolumn{5}{|c|}{ Scandals Connected to Jacob Zuma, Guptas, Other Key Networks and ANC Politics } \\
\hline \multicolumn{5}{|c|}{ State Capture of State-Owned Enterprises and Government Departments } \\
\hline \multirow{3}{*}{$\begin{array}{l}\text { Various } \\
\text { investigations } \\
\text { relating to } \\
\text { State Capture } \\
\text { at Eskom }\end{array}$} & 2015 & $\begin{array}{l}\text { In } 2015 \text {, Dentons produced an interim report } \\
\text { on their investigations into Status of Business } \\
\text { and Challenges at Eskom. Their investigation } \\
\text { was halted. }\end{array}$ & - Eskom & - Eskom \\
\hline & \multirow[t]{2}{*}{2017} & $\begin{array}{l}\text { In 2017, PricewaterhouseCoopers (PwC) was } \\
\text { appointed by National Treasury to investigate } \\
\text { Eskom's Coal Procurement Processes. Damning } \\
\text { findings were made in relation to Gupta-owned } \\
\text { Tegeta mine contracts and poor coal quality. }\end{array}$ & - Eskom & - Eskom \\
\hline & & $\begin{array}{l}\text { G9 was contracted by Eskom to investigate } \\
\text { the Trillian/McKinsey contracts. Interim report } \\
\text { presented to Board of Eskom in August } 2017 . \\
\text { The investigation remained incomplete, and } \\
\text { no report is available in the public domain. } \\
\text { Evidence from the investigation was presented } \\
\text { in the Parliamentary Inquiry into Eskom } \\
\text { State Capture. }\end{array}$ & $\begin{array}{l}\text { - National } \\
\text { Treasury }\end{array}$ & - Eskom \\
\hline $\begin{array}{l}\text { National } \\
\text { Treasury } \\
\text { Fundudzi } \\
\text { reports, } \\
\text { related to } \\
\text { Eskom and } \\
\text { Transnet (x3) }\end{array}$ & $\begin{array}{l}\text { Final reports } \\
\text { compiled in } \\
\text { November } 2018 \\
\text { and released to } \\
\text { the public shortly } \\
\text { thereafter. }\end{array}$ & $\begin{array}{l}\text { Investigations requested by National Treasury } \\
\text { of alleged corruption at Transnet and Eskom. } \\
\text { The three reports focused on Eskom (general), } \\
\text { the contracts related to Trillian/McKinsey and } \\
\text { Transnet Locomotives. }\end{array}$ & $\begin{array}{l}\text { - National } \\
\text { Treasury } \\
\text { Fundudzi }\end{array}$ & $\begin{array}{l}\text { - Eskom } \\
\text { - Transnet }\end{array}$ \\
\hline \multirow[t]{2}{*}{$\begin{array}{l}\text { Transnet } \\
\text { Locomotive } \\
\text { Contracts }\end{array}$} & \multirow[t]{2}{*}{$\begin{array}{l}\text { Investigations } \\
\text { commenced in } \\
\text { December } 2017 \\
\text { and reports on } \\
\text { findings submitted } \\
\text { during } 2018 .\end{array}$} & $\begin{array}{l}\text { Werksmans Attorneys was appointed in } \\
\text { December } 2017 \text { to undertake an investigation } \\
\text { into the } 1064 \text { Transnet Locomotives } \\
\text { procurement process, however, the investigation } \\
\text { was halted. No report in the public domain. }\end{array}$ & - Werksmans & - Transnet \\
\hline & & $\begin{array}{l}\text { Mncedisi Ndlovu \& Sedumedi (MNS) Attorneys } \\
\text { was then appointed to investigate } 1064 \\
\text { locomotives procurement process. The report } \\
\text { is not in the public domain, but media indicates } \\
\text { that recommendations mirror the Werksmans' } \\
\text { findings and recommends that Molefe face } \\
\text { criminal charges. }\end{array}$ & $\begin{array}{l}\text { - Mncedisi } \\
\text { Ndlovu \& } \\
\text { Sedumedi }\end{array}$ & - Transnet \\
\hline $\begin{array}{l}\text { Inquiry into } \\
\text { State Capture } \\
\text { at Transnet } \\
\text { and Denel }\end{array}$ & \begin{tabular}{l|} 
In June 2017, \\
Parliament directed \\
4 committees to \\
investigate state \\
capture. Committee \\
hearings were not \\
completed.
\end{tabular} & $\begin{array}{l}\text { A detailed information booklet was prepared } \\
\text { in relation to Transnet, however, hearings were } \\
\text { not held before the end of term of Parliament. } \\
\text { Following National elections in 2019, it } \\
\text { was decided that outstanding Inquiries into } \\
\text { state capture be postponed indefinitely until } \\
\text { conclusion of the Zondo Commission. }\end{array}$ & $\begin{array}{l}\text { - Portfolio } \\
\text { Committee } \\
\text { on Public } \\
\text { Enterprises }\end{array}$ & $\begin{array}{l}\text { - Transnet } \\
\text { - Denel }\end{array}$ \\
\hline
\end{tabular}




\begin{tabular}{|c|c|c|c|c|}
\hline $\begin{array}{l}\text { Case Study } \\
\text { in State } \\
\text { Capture }\end{array}$ & Status & Summary Description & $\begin{array}{l}\text { Investigation } \\
\text { Body / } \\
\text { Source of } \\
\text { Evidence }\end{array}$ & $\begin{array}{l}\text { Government } \\
\text { Entity } \\
\text { Implicated }\end{array}$ \\
\hline \multicolumn{5}{|c|}{ Scandals Connected to Jacob Zuma, Guptas, Other Key Networks and ANC Politics } \\
\hline \multicolumn{5}{|c|}{ Law Enforcement and the Security Cluster } \\
\hline $\begin{array}{l}\text { Enquiry into } \\
\text { Jiba and } \\
\text { Mrwebi's } \\
\text { fitness to } \\
\text { hold office } \\
\text { at NPA }\end{array}$ & $\begin{array}{l}\text { Established in } \\
\text { November } 2018 . \\
\text { Report was issued } \\
\text { in April } 2019 .\end{array}$ & $\begin{array}{l}\text { Presidential Enquiry into the fitness to hold } \\
\text { office of suspended NPA senior advocates } \\
\text { Nomgcobo Jiba and Lawrence Mrwebi. NPA's } \\
\text { deputy head Jiba, and Mrwebi, the head of } \\
\text { the Specialised Commercial Crimes Unit, were } \\
\text { suspended in October } 2018 \text { by President Cyril } \\
\text { Ramaphosa. The Inquiry was headed by retired } \\
\text { Constitutional Court Justice Yvonne Mokgoro. } \\
\text { Jiba and Mrwebi were accused of improper } \\
\text { conduct in their handling of cases involving } \\
\text { former crime intelligence head Richard Mdluli, } \\
\text { as well as former KwaZulu-Natal Hawks boss } \\
\text { Johan Booysen. }\end{array}$ & $\begin{array}{c}\text { - Mokgoro } \\
\text { Enquiry }\end{array}$ & $\begin{array}{l}\text { - } \text { National } \\
\text { Prosecuting } \\
\text { Authority }\end{array}$ \\
\hline $\begin{array}{l}\text { High-Level } \\
\text { Review Panel } \\
\text { on the State } \\
\text { Security } \\
\text { Agency (SSA) }\end{array}$ & $\begin{array}{l}\text { Established in June } \\
2018 \text { and final } \\
\text { report was sent to } \\
\text { the President in } \\
\text { December } 2018 .\end{array}$ & $\begin{array}{l}\text { The High-Level Review Panel into the SSA } \\
\text { was established by President Ramaphosa in } \\
\text { June 2018. The key finding was a serious } \\
\text { politicisation and factionalisation of the } \\
\text { intelligence community over the past decade } \\
\text { or more. This resulted in "an almost complete } \\
\text { disregard for the Constitution, policy, legislation } \\
\text { and other prescripts, and [turned] our civilian } \\
\text { intelligence community into a private resource } \\
\text { to serve the political and personal interests of } \\
\text { particular individuals" (High-Level Review Panel } \\
\text { on the SSA, 2018, p.ii). }\end{array}$ & $\begin{array}{l}\text { - Review } \\
\text { Panel } \\
\text { established } \\
\text { by President } \\
\text { Ramaphosa }\end{array}$ & - SSA \\
\hline $\begin{array}{l}\text { Various court } \\
\text { cases against } \\
\text { persons } \\
\text { within law } \\
\text { enforcement }\end{array}$ & Ongoing. & $\begin{array}{l}\text { Though testimony and evidence have been } \\
\text { presented at the Zondo Commission, it is } \\
\text { understood that no definitive findings will be } \\
\text { made regarding the capture of law enforcement } \\
\text { under the Zuma administration. Since } 2012 \\
\text { onwards, there were several court cases } \\
\text { that were pursued against individuals in law } \\
\text { enforcement, all of which have been either } \\
\text { dismissed or withdrawn. Most noteworthy are } \\
\text { the cases involved, amongst others: Anwa } \\
\text { Dramat and Shadrack Sibiya of the Hawks } \\
\text { (and Robert McBride from Independent Police } \\
\text { Investigative Directorate [IPID]) for allegations } \\
\text { related to the "Zimbabwean rendition" matter; } \\
\text { Johan Booysen for alleged racketeering as part } \\
\text { of "Cato Manor hit squad"; and the various } \\
\text { senior officials accused of being part of the } \\
\text { "rogue" intelligence unit at SARS. Other court } \\
\text { cases that have provided significant evidence } \\
\text { indicating the capture of law enforcement relate } \\
\text { to the irregular appointed allies of the Shadow } \\
\text { State capture network or the irrational removal } \\
\text { of potential opponents holding senior positions } \\
\text { in law enforcement. Example is the irregular } \\
\text { removal of Mxolisi Nxasana as National Director } \\
\text { of Public Prosecutions (NDPP). }\end{array}$ & $\begin{array}{l}\text { - Various } \\
\text { court cases, } \\
\text { proceedings } \\
\text { in Parlia- } \\
\text { ment } \\
\text { - Zondo } \\
\text { Commission }\end{array}$ & $\begin{array}{l}\text { - NPA } \\
\text { - SAPS } \\
\text { - Hawks } \\
\text { - IPID }\end{array}$ \\
\hline
\end{tabular}




\begin{tabular}{|c|c|c|c|c|}
\hline $\begin{array}{l}\text { Case Study } \\
\text { in State } \\
\text { Capture }\end{array}$ & Status & Summary Description & $\begin{array}{l}\text { Investigation } \\
\text { Body / } \\
\text { Source of } \\
\text { Evidence }\end{array}$ & $\begin{array}{l}\text { Government } \\
\text { Entity } \\
\text { Implicated }\end{array}$ \\
\hline \multicolumn{5}{|c|}{ Scandals Connected to Jacob Zuma, Guptas, Other Key Networks and ANC Politics } \\
\hline \multicolumn{5}{|c|}{ Investigations concerning Private Sector } \\
\hline $\begin{array}{l}\text { Budlender } \\
\text { report on } \\
\text { Trillian }\end{array}$ & $\begin{array}{l}\text { Released in } \\
\text { June } 2017 .\end{array}$ & $\begin{array}{l}\text { Trillian Holdings Board appointed Geoff } \\
\text { Budlender SC to undertake investigations into } \\
\text { State Capture allegations at Trillian Capital. } \\
\text { Detailed accounts from whistle-blowers } \\
\text { highlighted how information was withheld by } \\
\text { senior management at Trillian. }\end{array}$ & - Trillion & - Eskom \\
\hline $\begin{array}{l}\text { Collapse of } \\
\text { VBS Mutual } \\
\text { Bank }\end{array}$ & $\begin{array}{l}\text { Investigation } \\
\text { launched in } \\
\text { April } 2018 \text { and } \\
\text { the report was } \\
\text { released in } \\
\text { October } 2018 .\end{array}$ & $\begin{array}{l}\text { Minister of Finance placed VBS under } \\
\text { curatorship with effect from } 11 \text { March 2018. In } \\
\text { April 2018, the Deputy Governor of the South } \\
\text { African Reserve Bank instituted an investigation } \\
\text { into VBS. The outcomes of the investigation } \\
\text { showed blatant fraud and corruption by senior } \\
\text { executives/Board and how they extracted } \\
\text { money from the bank. Municipal funds were } \\
\text { illegally deposited with VBS (senior ANC and } \\
\text { EFF politicians have been implicated). }\end{array}$ & $\begin{array}{l}\text { - SARB } \\
\text { investiga- } \\
\text { tion report } \\
\text { VBS Mutual } \\
\text { Bank - The } \\
\text { Great Bank } \\
\text { Heist }\end{array}$ & $\begin{array}{l}\text { - Several } \\
\text { Provincial and } \\
\text { Municipal } \\
\text { Officials } \\
\text { (Limpopo } \\
\text { Government) } \\
\text { - SOEs } \\
\text { (particularly } \\
\text { PRASA) }\end{array}$ \\
\hline $\begin{array}{l}\text { SA Institute } \\
\text { of Chartered } \\
\text { Accountants' } \\
\text { (SAICA) } \\
\text { investigation } \\
\text { into KPMG }\end{array}$ & $\begin{array}{l}\text { Final report was } \\
\text { handed to SAICA in } \\
\text { December } 2018 .\end{array}$ & $\begin{array}{l}\text { SA Institute of Chartered Accountants (SAICA) } \\
\text { established an Inquiry to investigate state } \\
\text { capture related allegations of misconduct of its } \\
\text { members who worked for KPMG. The Inquiry } \\
\text { chaired by advocate Dumisa Ntsebeza held } \\
\text { public hearings and handed its final report to } \\
\text { SAICA in December 2018. Indications are that } \\
\text { the final report will not be made public until all } \\
\text { investigations and disciplinary hearings have } \\
\text { been finalised. }\end{array}$ & - SAICA & - Guptas \\
\hline Bell Pottinger & $\begin{array}{l}2017 \text { investigation } \\
\text { by PRCA. }\end{array}$ & $\begin{array}{l}\text { In 2016, the Guptas appointed British PR } \\
\text { company, Bell Pottinger, who developed and } \\
\text { promoted a campaign that underpinned the RET } \\
\text { and WMC narratives. In 2017, there was an } \\
\text { independent law firm review by Herbert Smith } \\
\text { Freehills resulting in Bell Pottinger's expulsion } \\
\text { from the Public Relations and Communications } \\
\text { Association (PRCA). }\end{array}$ & $\begin{array}{l}\text { - PRCA } \\
\text { - GuptaLeaks } \\
\text { - Ongoing } \\
\text { research } \\
\text { on disinfor- } \\
\text { mation }\end{array}$ & - Guptas \\
\hline
\end{tabular}

